DOI 10.31558/2307-2318.2020.3.8
УДК 330.341 .1
JEL: R4

Буркіна Н.В.,

к.п.н., доцент, доцент кафедри економічної та управлінської аналітики, Донецький національний університет імені Василя Стуса

ORCID: 0000-0003-2993-5128

n.burkina@donnu.edu.ua

Капітонець М.В.,

Донецький національний університет імені Василя Стуса

ORCID: 0000-0003-0572-0843

kapitonets.m@donnu.edu.ua

\title{
АНАЛІЗ РИНКУ ЛОГІСТИКИ УКРАЇНИ: СТАТИСТИЧНИЙ АСПЕКТ
}

У статті представлені результати аналізу вітчизняного ринку логістики та проведено аналіз основних показників ефективності логістичної діяльності. Проаналізовано вплив транспортно-експедиторської діяльності на розвиток економіки краӥни. Досліджено теоретичний аспект транспортно-експедиторських послуг та наведено їх основні види. Також у статі було прогнозовано майбутні значення основних показників стану ринку логістики. Метою статті $\epsilon$ аналіз стану розвитку ринку логістики в Україні, дослідження транспортно-експедиторських підприємств, дослідження теоретичного аспекту транспортно-експедиторської діяльності згідно чинного законодавства України, класифікащії основних видів транспортноекспедиторських послуг. Проаналізовано наукові публікації вітчизняних та зарубіжних вчених. Здійснено статистичний аналіз ринку логістики Украйни. Досліджено динаміку розвитку логістичного ринку Украӥни за допомогою Індексу логістичної ефективності та здійснено його прогнозні значення на майбутнє. Проведено аналіз структури основних показників Індексу логістичної ефективності та виявлено сильні та слабкі сторони вітчизняного ринку логістичних послуг.

Ключові слова: логістика, транспортно-експедиторські послуги, LPI, адаптивні моделі прогнозування, модель Брауна.

Рис. -7 , Літ. -14

\section{Буркина Н.В.,}

к.п.н., доцент, доцент кафедры экономической и управленческой аналитики Донецкий национальный университет имени Василия Стуса

ORCID: 0000-0003-2993-5128

n.burkina@donnu.edu.ua 
Капитонець М.B.,

Донецкий национальный университет имени Василия Стуса

ORCID: 0000-0003-0572-0843

kapitonets.m@donnu.edu.ua

\section{АНАЛИЗ РЫНКА ЛОГИСТИКИ УКРАИНЫ: СТАТИСТИЧЕСКИЙ АСПЕКТ}

В статье представлены результаты анализа отечественного рынка логистики и проведен анализ основных показателей эффективности логистической деятельности. Проанализировано влияние транспортно-экспедиторской деятельности на развитие экономики страны. Исследован теоретический аспект транспортно-экспедиторских услуг, приведены их основные виды. Также в статье было прогнозируемо будущие значения основных показателей состояния рынка логистики. Целью статьи является анализ развития рынка логистики в Украине, исследования транспортноэкспедиторских предприятий, исследования теоретического аспекта транспортноэкспедиторской деятельности согласно действующему законодательству Украины, классификации основных видов транспортно-экспедиторских услуг. Проанализировань научные публикации отечественных и зарубежных ученых. Осуществлен статистический анализ рынка логистики Украиньл. Исследована динамика развития логистического рынка Украины с помощью Индекса логистической эффрективности и осуществлено его прогнозные значения на будущее. Проведен анализ структурь основных показателей Индекса логистической эффективности и выявлены сильные и слабые стороны отечественного рынка логистических услуг.

Ключевые слова: логистика, транспортно-экспедиторские услуги, LPI, адаптивные модели прогнозирования, модель Брауна.

Рис. - 7, Лит. -14

\section{N. Burkina,}

Ph.D., Associate Professor, Associate Professor of Economic and Management Analytics,

Vasyl' Stus Donetsk National University

ORCID: 0000-0003-2993-5128

n.burkina@donnu.edu.ua

M. Kapitonets,

Vasyl' Stus Donetsk National University, ORCID: 0000-0003-0572-0843

kapitonets.m@donnu.edu.ua

\section{ANALYSIS OF THE LOGISTICAL MARKET OF UKRAINE: STATISTICAL ASPECT}

The article presents the results of the analysis of the domestic logistics market and analyzes the main indicators of logistics efficiency. The influence of transport and forwarding 
activities on the development of the country's economy was analyzed. The theoretical aspect of freight forwarding services is studied and presents their main type. The article also predicted the future values of the main indicators of the logistics market. The purpose of the article is to analyze the state of development of the logistics market in Ukraine, study of freight forwarding companies, study the theoretical aspect of freight forwarding activities according to current legislation of Ukraine, classification of major types of freight forwarding services. Scientific publications of domestic and foreign scientists are analyzed. The statistical analysis of the logistics market of Ukraine is carried out. The dynamics of the development of the logistics market of Ukraine is studied with the help of the Logistics Efficiency Index and its forecast values for the future are made. The structure of the main indicators of the Logistics Efficiency Index is analyzed and the strengths and weaknesses of the domestic market of logistics services are identified.

Keywords: logistics, freight forwarding services, LPI, adaptive forecasting models, Brown model.

Fig. -7 , Ref. -14

Постановка проблеми в загальному вигляді. В умовах інтеграції світового господарства, вагомого значення набуває необхідність транспортного забезпечення для здійснення внутрішньої та зовнішньої торгівлі, яке виконують транспортноекспедиторські підприємства. При цьому вони реалізують функцію створення транспортного конвеєра, забезпечуючи тим самим доставку товарів та послуг до споживачів. Згідно досліджень Всесвітнього банку, Індекс логістичної ефективності в Україні становить 2,83 станом на 2018 рік, таким чином, Україна зайняла 66 місце з 160 країн світу. Транспортно-експедиторські підприємства допомагають здійснювати перевезення та виконують роль посередництва. Тому необхідним $є$ подальше дослідження теоретичного аспекту транспортно-експедиторської діяльності, здійснення статистичного аналізу стану ринку вітчизняної логістики.

Аналіз останніх публікацій та досліджень. Дослідженню теоретичних аспектів щодо поняття, ефективності і функціонування транспортно-експедиторських послуг приділили свою увагу такі науковці, як Д.О. Власенко, В.В. Луць, Г.В. Самойленко, Н.В. Федорченко, В.Н. Лівшиць, Н.Т. Примачов, В.М. Баровський, Г.А. Воркут, І.А. Діковська, Л.Я. Свистун, О.С Кужко та ін.

Метою статті $\epsilon$ аналіз стану розвитку ринку логістики в Україні, дослідження транспортно-експедиторських підприємств, дослідження теоретичного аспекту транспортно-експедиторської діяльності згідно чинного законодавства України, класифікації основних видів транспортно-експедиторських послуг.

Виклад основного матеріалу дослідження. Інтеграція світового господарства, розвиток транспортних мереж та світового ринку логістичних послуг, поглиблення міжнародного поділу праці - все це свідчить про необхідність дослідження стану розвитку ринку логістики. Логістика $\epsilon$ ефективним засобом підвищення стану конкурентоспроможності вітчизняних підприємств. Аналіз тенденції логістичного ринку дозволяє дослідити проблему забезпечення розвитку такого сегменту, як транспортноекспедиційні послуги на вітчизняному ринку.

Логістика в Україні розвивається відповідно до світових тенденцій, здійснюючи вагомий вплив на національний економічний потенціал, стимулює розвиток взаємопов'язаних i суміжних галузей, виступаючи індикатором конкурентоспроможності нашої держави у світі [1]. 
Однією із найважливіших галузей економіки є транспорт, який свідчить про ефективне функціонування виробничо-господарської діяльності країни. Для забезпечення стабільного процесу роботи галузі існує велика кількість транспортноекспедиційних, транспортних, комплексних логістичних операторів, інформаційнопосередницьких компаній та ін. Серед даних суб'єктів ринку найбільшу частку ринку займають транспортно-експедиційні підприємства.

Згідно зі ст. 1 Закону № 1955 транспортно-експедиторська діяльність підприємницька діяльність із надання транспортно-експедиторських послуг з організації та забезпечення перевезень експортних, імпортних, транзитних або інших вантажів [2]; транспортно-експедиторська послуга - робота, що безпосередньо пов'язана 3 організацією та забезпеченням перевезень експортного, імпортного, транзитного або іншого вантажу, за договором транспортного експедитування» [3].

До видів транспортно-експедиторської послуг відноситься:

1) організація охорони та експертизи вантажів;

2) забезпечення оптимального транспортного обслуговування;

3) організація перевезень вантажів за допомогою різних видів транспорту;

4) залучення інших транспортних засобів та ін [2].

Таким чином експедиторська діяльність являє собою сукупність різних послуг пов'язаних з перевезенням вантажу. Проте існує ще декілька класифікацій транспортних послуг, зокрема:

1. За об’єктом транспортної процедури

1. пасажирські

2. вантажні за призначенням: імпортні; експортні; транзитні

3. вантажні за особливістю транспортування: наливні; насипні; контейнерні; тарно-штучні; навальні.

2. За суб'єктом транспортної операції залежно від виду споживача, якому буде надаватись послуга:

1. зовнішньогалузеві;

2. внутрішньогалузеві

3. За видом діяльності:

1) перевізні;

- за видом транспорту: водні, залізничні, автомобільні, повітряні, змішані.

- за територіальною ознакою: внутрішньодержавні та міжнародні;

- за періодичністю: регулярні та нерегулярні;

- за видами сполучень: прямі та непрямі;

- за видом транспортно-технологічної системи: пакетні. контейнерні; ролкерні та iH.

2) неперевізні.

- Комплексно-експединційні:

1. Послуги з відправки (прийом, маркування і пакування вантажів, оформлення відповідної документації);

2. Послуги по супроводу вантажу (забезпечення цілісності вантажів в дорозі, організація необхідних перевантажень і безпосереднє транспортування);

3. Послуги прибуття (контроль за прибуттям, інформування про надходження вантажів, організація розвантаження транспортних засобів, оформлення документів, звіт перед вантажовідправником та інші).

Розвиток транспортно-експедиторських послуг позитивно впливає на розвиток ринкових відносин, зокрема: 
1) ефективно впливає на раціональне використання ресурсів;

2) розвиток конкуренції;

3) зниження витрат на перевезення, розміщення та складування вантажу тощо.

У загальносвітовому експорті та імпорті всіх видів послуг частка транспортних послуг становить приблизно 24\% (5,5 трлн. дол США). Звичайно, постачальники транспортно-експедиційних послуг на світовий ринок програють за вартісними показниками експортерам товарів, але тільки найбільшим [4].

Нині в Україні спостерігається позитивна тенденція розвитку логістики, про це свідчать дані звіту Світового банку щодо індексу ефективності логістики (рис.1). Серед 160 країн світу Україна посідає 66 місце (LPI=2,83) в 2018 році проти 80 в 2016 (LPI=2,74).

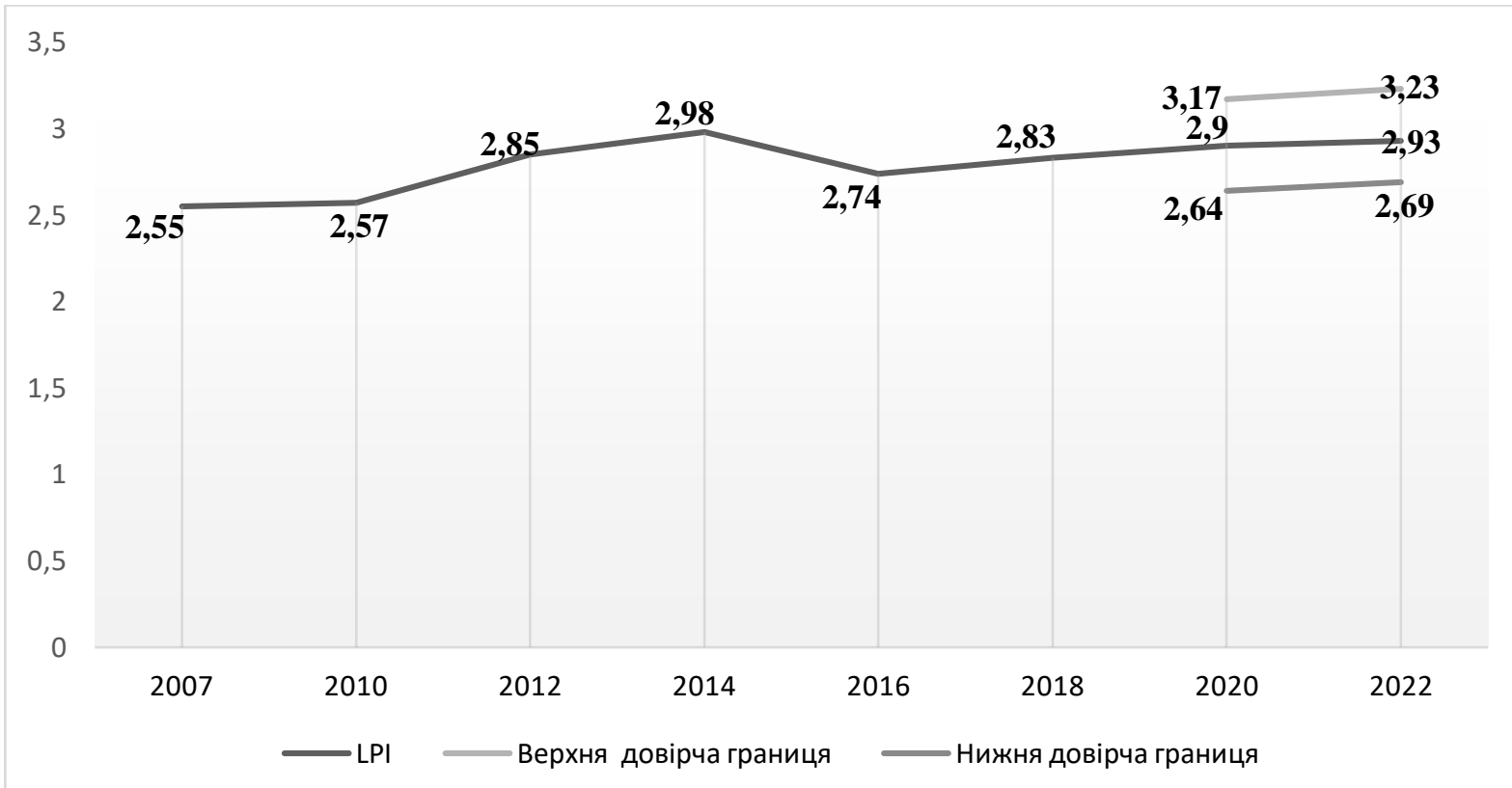

Рисунок 1 - Динаміка розвитку LPI в Україні з 2007-2018 рp. та прогнозні значення на 2020 та 2022 рр.

Джерело: сформовано на основі [5]

LPI грунтується на всесвітньому опитуванні місцевих операторів (глобальних транспортно-експедиторських і експрес-перевізників), забезпечуючи зворотний зв'язок щодо логістичної "дружності" країн, в яких вони працюють, і тими, з якими вони торгують. Вони поєднують в собі глибокі знання про країни, в яких вони здійснюють свою діяльність 3 поінформованими якісними оцінками інших країн, де вони торгують $і$ досвід глобального навколишнього середовища логістики [6].

До індексу LPI (Logistics Performance Index) входять:

- митна логістика;

- логістична компетентність;

- інфраструктура;

- спостереження за пересуванням вантажу;

- логістична компетентність (якість логістичних послуг та компетентність)

- своєчасність ( своєчасність доставки вантажу до пункту призначення відповідно до запланованого терміну) . 
В Україні найбільш розвиненим є показник своєчасності поставок вантажу (станом на 2018 рік він становить 3,42 бали), а найменш розвиненим показник інфраструктури (2,22 бали). Структура LPI по роках наведена на рисунку 2.

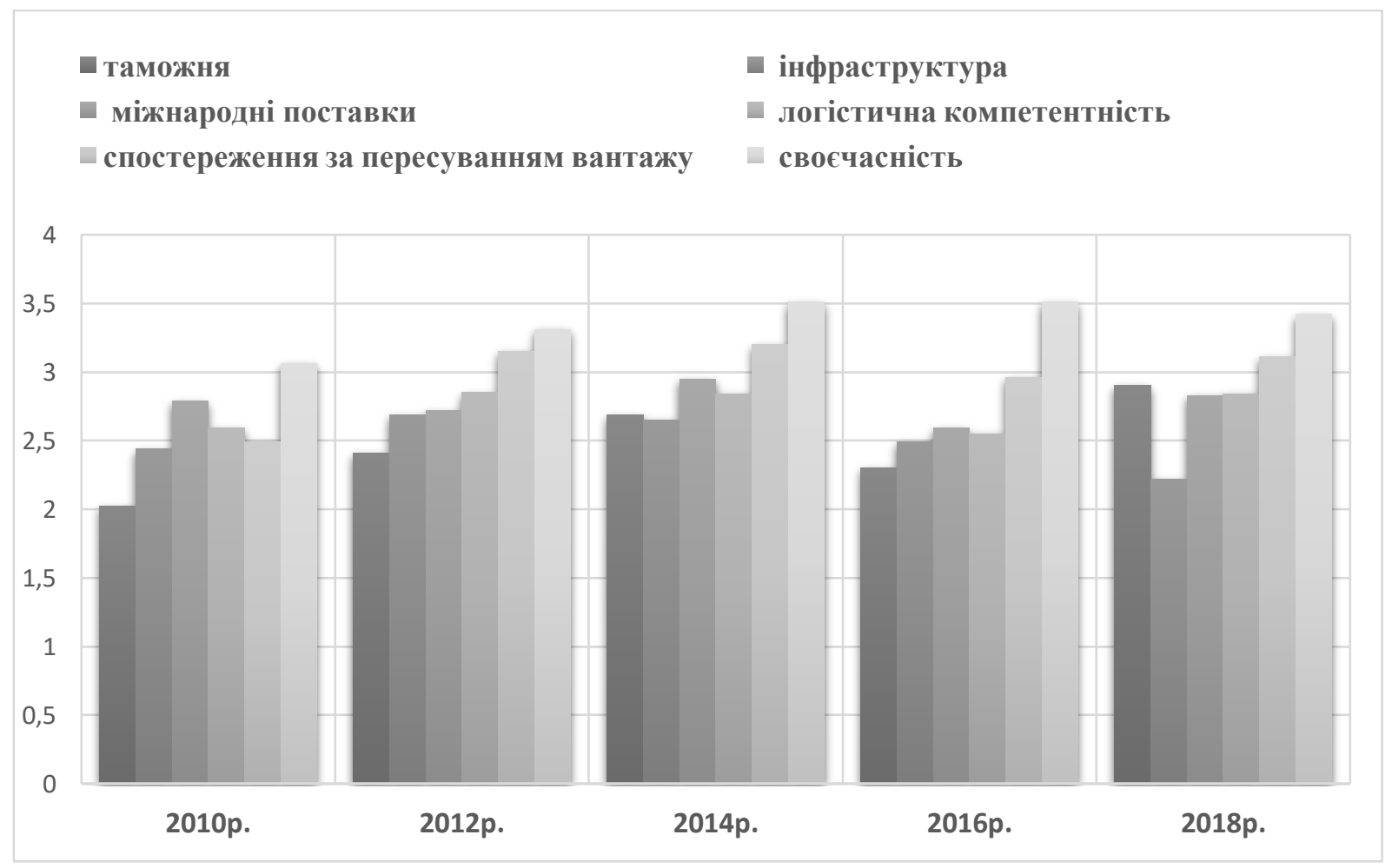

Рисунок 2 - Динаміка структури LPI по роках

Джерело: сформовано на основі [7]

Стверджується, що визначальними трендами глобальної логістики $\epsilon$ зосередженість на виконанні термінових замовлень та забезпечення рентабельності їх виконання. У зв'язку з цим конкурентних переваг набувають ті експедитори, які впроваджують технологічні інновації, пов'язані з гнучкістю виконання замовлень та цифровими технологіями з метою зниження загальних витрат у мережі. Розвиток багатоканальних мереж доставки продукції в т.ч. поширення електронної роздрібної торгівлі, призвів до високих темпів зростання сектору експрес-доставки вантажів [8].

Нині всі основні експедиторські фірми об'єднані Асоціацією міжнародних експедиторів України (АМЕУ) i Асоціацією «Укрзовніштранс», які входять у Міжнародну Федерацію експедиторських асоціацій (FIATA). Членами AMEУ є більше 172 транспортно-експедиторських організацій усіх форм власності, а до «Укрзовніштранс» належать 34 компанії. Вони здійснюють експедиторське обслуговування в усіх регіонах України, працюють з усіма видами транспорту. На частку компаній, що входять у ці асоціації, припадає близько 50 \% імпорту і експорту та близько $70 \%$ транзиту [9].

Логістичний ринок України включає в себе такі види вантажоперевезень, як: залізничні, автомобільні, авіаційні, водні (морські та річкові). Найбільш розвиненим $є$ залізничний вид перевезень він займає $54 \%$ ринку, а найменш розвиненим водний, який складає лише $0,01 \%$. На рисунку 3 відображено порівняльну структуру ринку логістики за 2013 та 2018 рр. Спостерігається тенденція до зниження частки залізничного виду перевезень з 58\% до 52\%, і збільшення частки автомобільних перевезень на 6\%. 

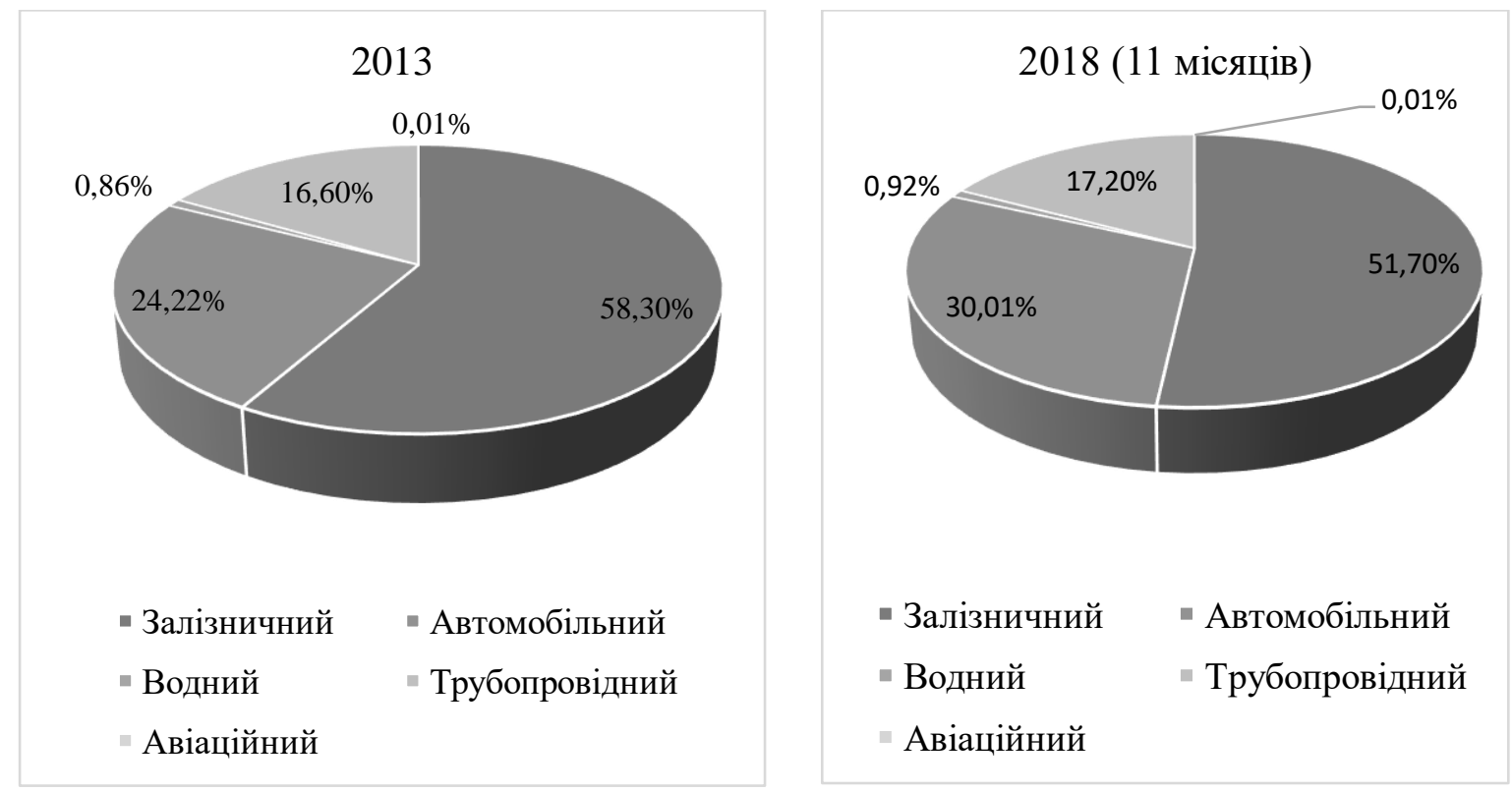

\section{Рисунок 3 - Структура вантажообігу в розрізі видів транспорту - 2013 та 2018 (11 місяців) pp.}

Джерело: сформовано на основі [7]

Дослідження динаміки обсягів вантажообігу наземного транспорту (рис.4) свідчить про їх зменшення, на що впливає низка факторів: дестабілізація політичних процесів в країні, антитерористична операція на сході країни, втрата АР Крим, дефіцит транспорту, втручання інших держав в політику країни та ін.

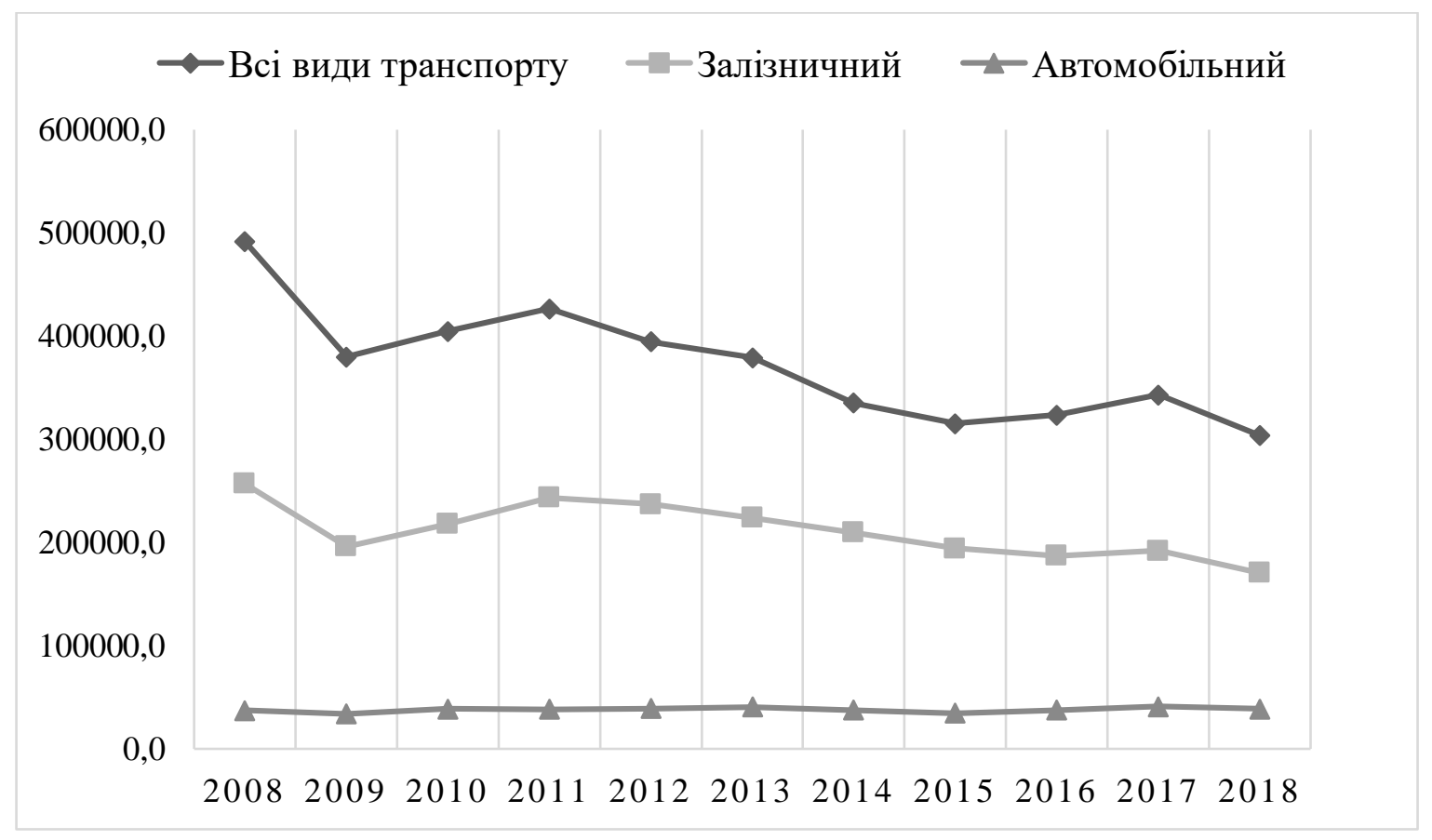

Рисунок 4 - Динаміка вантажообігу наземних транспортних підприсмств за 20132017 рр (млн.т/км)

Джерело: сформовано на основі [7] 
Загальна потужність українського ринку транспортних та логістичних послуг складає 438,740 млрд. грн. Більша частина вантажних перевезень припадає на наземний транспорт - 97\%, а решта $3 \%$ розподіляються між водними та повітряними перевезеннями. Найбільша частка належить залізничному транспорту - 52\%\%, що переважає на внутрішньому ринку $[6 ; 7 ; 11]$.

Статистичне моделювання та прогнозування є процесом, який включає декілька етапів: аналіз наявності тенденції, визначення та побудова тренду, побудова адаптивної моделі, побудова авторегресійної моделі [12]

Для перевірки наявності тенденції був використаний метод Фостера-Стьюарта та істотної різниці середніх. Ці методи дозволяють виявити залежність між даними ряду.

Використання методу Фостера-Стьюарта, дозволило зробити наступний висновок, що ряд статистично неоднорідний, тому гіпотеза про істотність різниці середніх не відкидається. За допомогою методу істотної різниці середніх, робимо висновок, що у зв'язку з тим, що t розр (d)> t табл, то гіпотеза про наявність тенденції в середньому не відкидається і вона дає можливість моделювати цю тенденцію.

Другим етапом є визначення та побудова тренду. Для цього побудуємо графіки поліному (рис.5).

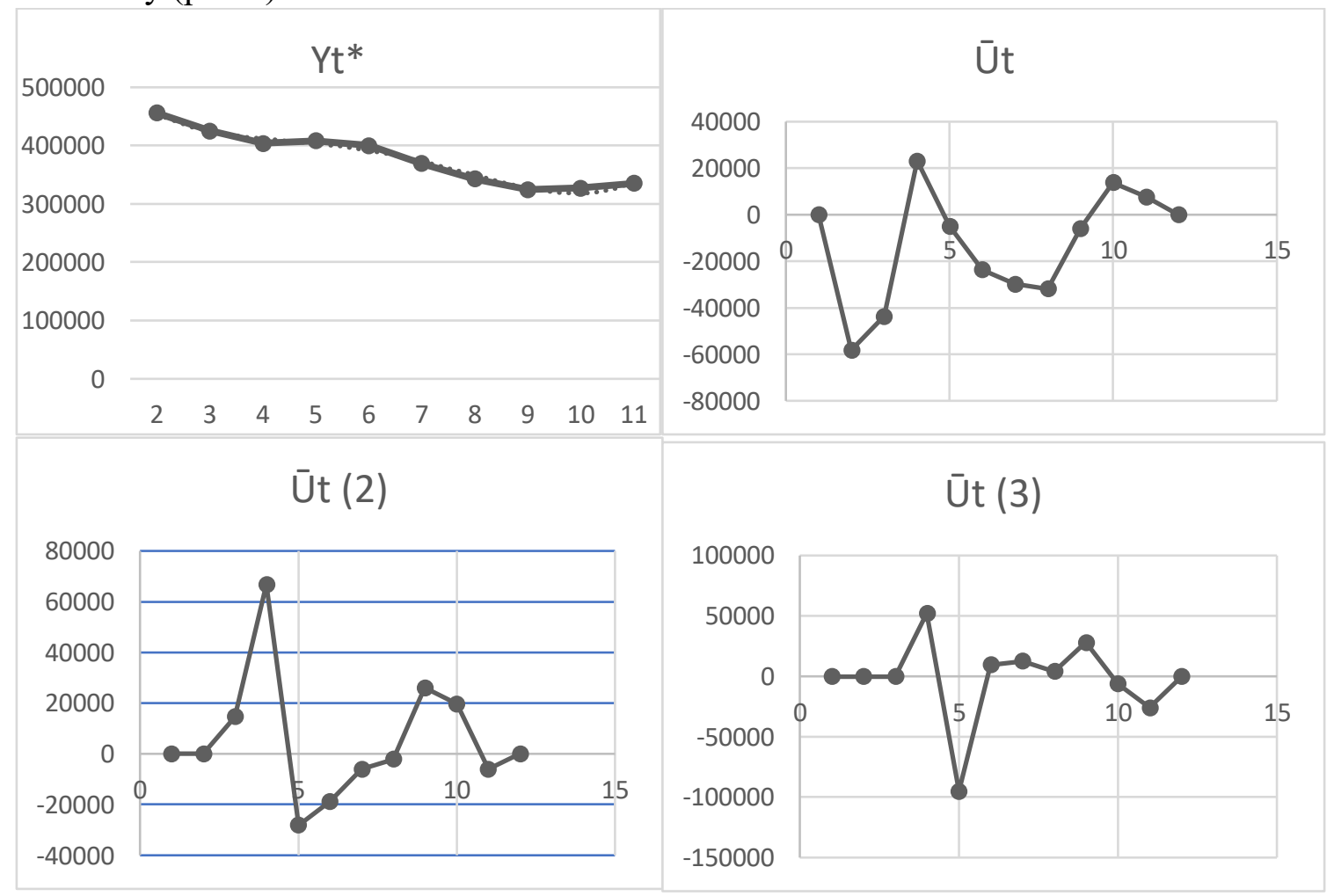

\section{Рисунок 5 - Аналіз вибору ступеня полінома}

При виборі ступеня полінома, ми керуємось вибором найменшого відхилення. У даному випадку, найбільш оптимальним є графік Ut (Рис.5).

Наступним етапом буде побудова адаптивної моделі. Для цього скористаємось одним iз екстраполяційних методів короткострокового прогнозування. При короткостроковому прогнозуванні, а також при прогнозуванні в ситуації зміни зовнішніх умов, коли найбільш важливими є останні реалізації досліджуваного процесу найбільш ефективними виявляються адаптивні методи, що враховують нерівноцінність рівнів 
тимчасового ряду [13]. Проведемо аналіз по моделях Брауна. Результати відображені на рисунках 6 та 7.

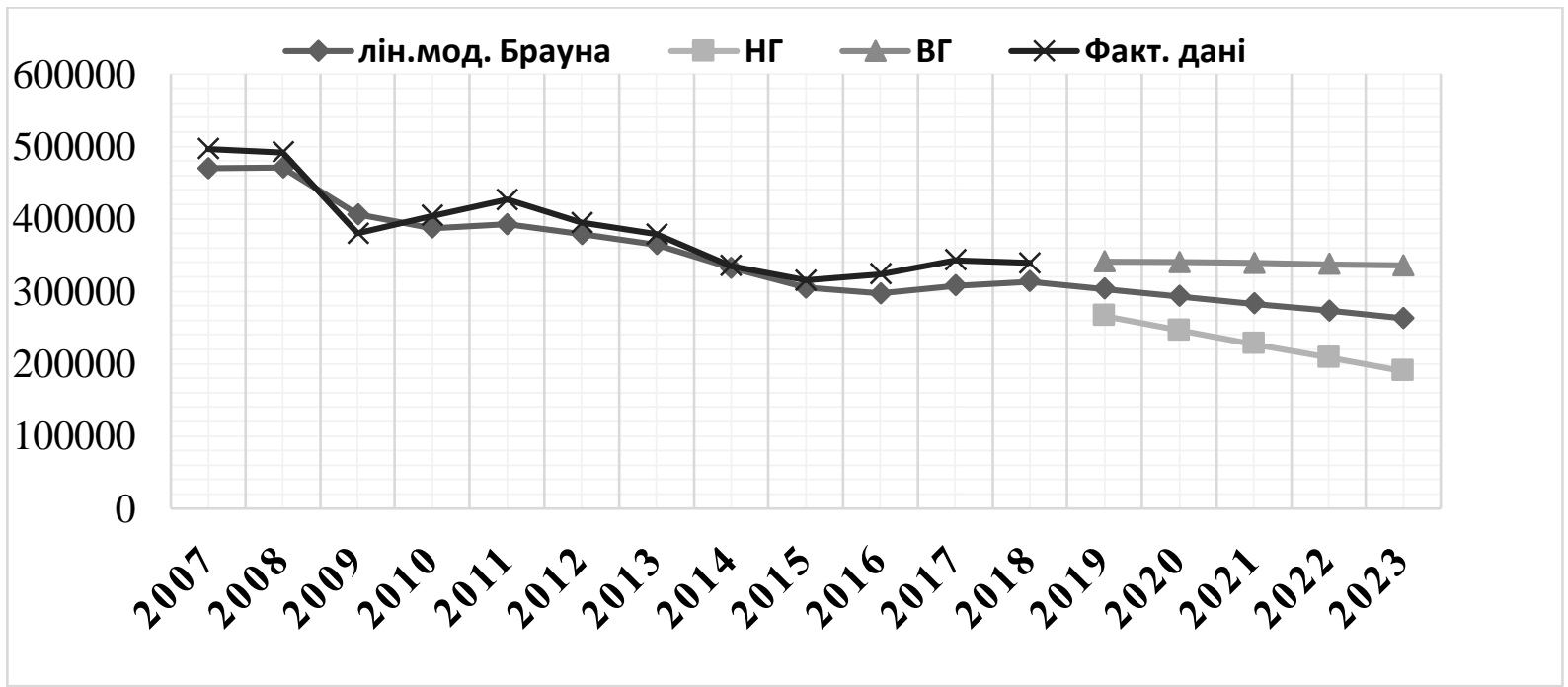

Рисунок 6 - Результати прогнозування по лінійній моделі Брауна

Після ідентифікації лінійної моделі Брауна перевіряється статистична достовірність і точність моделі за відповідними критеріями. Для статистичної достовірності застосовується $\mathrm{F}$-критерій : $\mathrm{F}_{\text {розр. }}>\mathrm{F}_{\text {табл. }}(48,05 .>4,96)$, тому гіпотеза статистичної достовірності лінійної моделі Брауна 3 ймовірністю 0,95 не відкидається.

Статистична точність перевіряється за допомогою відносної помилки апроксимації. Оскільки $\varepsilon_{\text {вiдн}}(5,57)<15 \%$, то модель відповідає критерію статистичної точності.

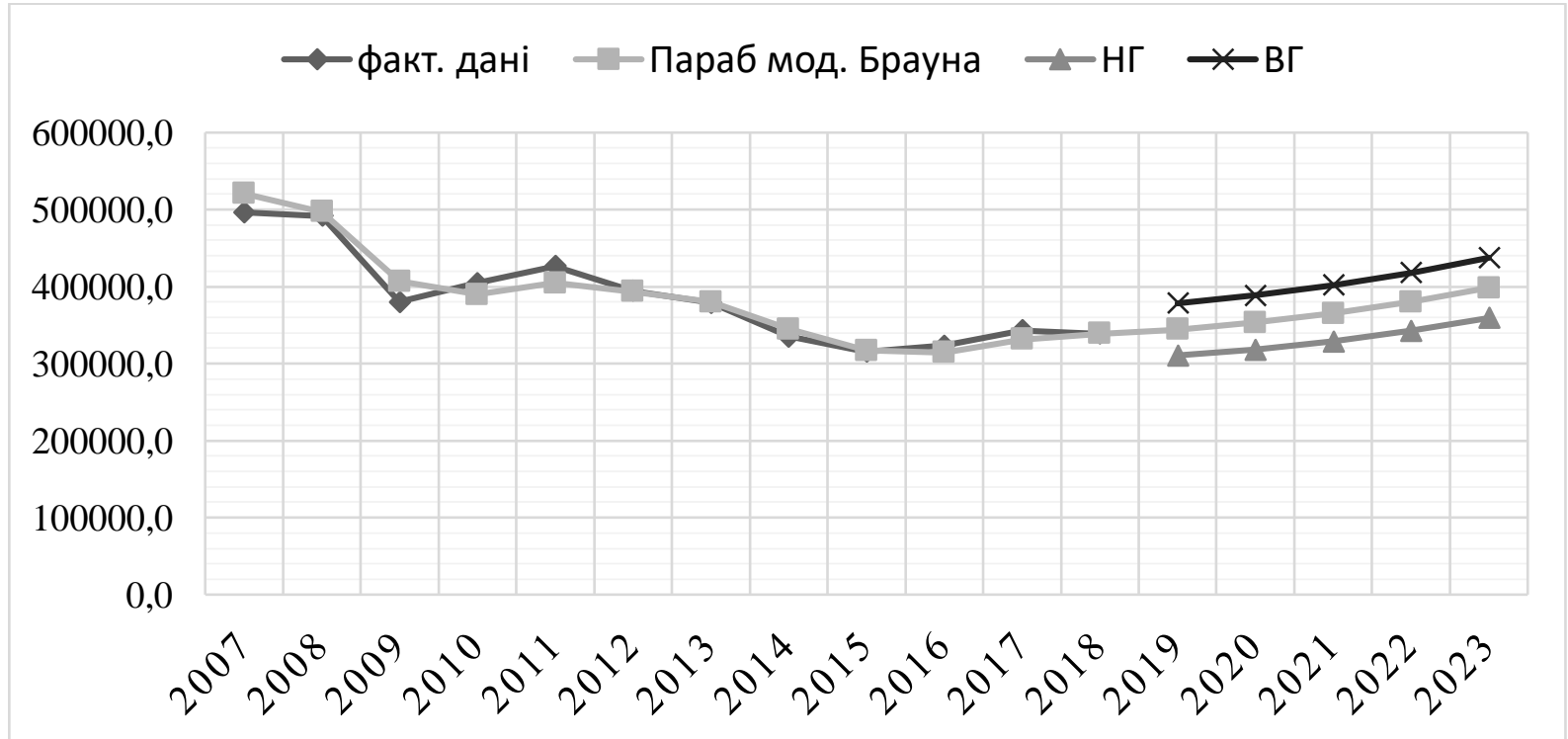

Рисунок 7 - Результати прогнозування по параболічній моделі Брауна (параболічна модель) 
Після ідентифікації параболічної моделі Брауна перевіряємо точність моделі. Оскільки $\varepsilon_{\text {відн }}(2,67)<15 \%$, то модель відповідає критерію статистичної точності. За результатами дослідження можна сказати, що параболічна модель Брауна найбільше підходить для прогнозування вантажообігу, оскільки вона має найменшу помилку. В результаті дослідження, можна зробити висновок, що обсяги вантажообігу в Україні залишаються на високому рівні.

Висновки. Отже, логістичні послуги займають вагоме місце в світовому господарстві. На вітчизняному ринку вона знаходиться в стадії розвитку. Аналіз динаміки індексу логістичної ефективності показав поступовий розвиток сфери логістики на вітчизняному ринку, незважаючи на ряд факторів, які перешкоджають іiі діяльності (економічна криза, несприятлива політична ситуація в країні, війна на сході України та ін.).

Однією із найважливіших складових ринку логістики є транспорт. Він відіграє важливу роль у розвитку національного господарства країни. Сьогодні найбільшу частку вантажів переміщує залізничний транспорт (близько 52\%), що відповідає офіційним статистичним даним, проте реальні показники можуть значно відрізнятись, оскільки показники перевезень вантажу автомобільним видом транспорту не включають в себе деякі вагомі дані про перевезення.

\section{СПИСОК ВИКОРИСТАНИХ ДЖЕРЕЛ}

1. Статистичний аналіз структури та тенденцій розвитку логістичного ринку України / Р. В. Ціщик, Н. В. Котис // Проблеми системного підходу в економіці. - 2018. - Вип. 3(1). - C. 54-59. - Режим доступу: http://nbuv.gov.ua/UJRN/PSPE_print_2018_3\%281\%29_11

2. Транспортно-експедиторські послуги в Україні [Електронний ресурс] // Вісник Міністерства дохолів і зборів України. - 2014. - Режим доступу до ресурсу: http://www.visnuk.com.ua/uk/issue/159

3. Закон України «Про транспортно-експедиційну діяльність» від 01.07. 2004 № 1955IV. http://zakon2.rada.gov.ua/laws/show/1955-15

4. Глушенко Т.М. Аналіз розвитку логістичних послуг на сучасному світовому ринку / T.М. Глушенко // Науковий вісник Херсонського державного університету. - 2014. Вип. 6. Ч. 1. - С. 169-171

5. Logistics Performance Index. Website of World Bank. URL: https://lpi.worldbank.org/report

6. Більовський К.Е. Стан та перспективи розвитку ринку логістичних послуг в Україні / К.Е. Більовський // Вісник Хмельницького національного університету. - 2016. - № 4. T. 2. - C. $25-29$

7. Державна служба статистики України [Електронний ресурс]. - Режим доступу: http://www.ukrstat.gov.ua/

8. Шандрівська О. Є. Дослідження глобального ринку логістичних послуг: світові тенденції та вплив на Україну / О. Є. Шандрівська, Л. Я. Якимишин // Вісник Національного університету “Львівська політехніка". Серія: Логістика. - Львів : Видавництво Львівської політехніки, 2018. - № 892. — С. 212-221.

9. Григорак М. Ю. Анализ рынка логистических услуг в Украине/ М. Ю. Григорак, В. В. Коцюба // Логистика: проблемы и решения. - 2006. -№2(3). -С. 21-29

10. Сухорська У.Р. Маркетингова політика розподілу : навч. посіб. / Сухорська У.Р., Щербань В.М. - Л. : Вид-во Львів. комерц. акад., 2015. - 383 с

11. Особливості ринку логістичних послуг в Україні. URL: https:/proconsulting.ua/ua/pressroom/ osobennosti-rynka-logisticheskih-uslug-v-ukraine 
12. Буркіна Н. В.Статистичне моделювання і прогнозування : робочий зошит для студентів всіх спеціальностей економічного факультету. Вінниця : ДонНУ імені Василя Стуса, 2018. 55 c

13. Матвієнко Т. В. Дослідження короткострокового прогнозування - модель Брауна / Матвієнко Т. В., Цеслів О. В. // Актуальні проблеми економіки та управління : збірник наукових праць молодих вчених. - 2009. - Вип. 3. - С. 132-134.

14. Швидше за все повезе, ось тільки на чому? Аналіз ринку вантажоперевезень в Україні [Електронний ресурс] // Pro Capital Group. - 2019. - Режим доступу до ресурсу: https://pro-consulting.ua/ua/services?type

\section{REFERENCES}

1. Cishhyk, R., Kotys, N., (2018) Statistical analysis of the structure and development trends of the logistics market of Ukraine. Problems of system approach in economy. 3(1), 164.01:311 2. Transport and forwarding services in Ukraine (2014)., Bulletin of the Ministry of Revenue and Duties of Ukraine.

3. Law of Ukraine "On transport and forwarding activities" from 01.07. 2004 № 1955-IV http://zakon2.rada.gov.ua/laws/show/1955-15.

4. Glushenko, T., (2014). Analysis of the development of logistics services in the modern world market. Scientific Bulletin of Kherson State University, 6. Part 1., 656.025.2

5. Logistics Performance Index. Website of World Bank. URL: https://lpi.worldbank.org/report

6. Bilyovsky, K., (2016) The state and prospects of the logistics services market in Ukraine. Bulletin of Khmelnytsky National University, 4., Vol. 2. 658.7

7. State Statistics Service of Ukraine [Electronic resource]. - Access mode: http://www.ukrstat.gov.ua/

8. Shandrivska, O., Yakymyshyn, L., (2018). Research of the global market of logistics services: world tendencies and influence on Ukraine. Bulletin of the National University "Lviv Polytechnic". 892, 339.188.

9. Grigorak, M., Kotsyuba, V., (2006) Analysis of the logistics services market in Ukraine. Logistics: problems and solutions. 2 (3).

10. Sukhorska, U., Shcherban, V., (2015). Distribution marketing policy. Tutorial. Lviv Publishing House. commerce. acad.,

11. Features of the market of logistics services in Ukraine. URL: https://proconsulting.ua/en/pressroom/ osobennosti-rynka-logisticheskih-uslug-v-ukraine

12. Burkina, N., Statistical modeling and forecasting: a workbook for students of all specialties of the Faculty of Economics. Vinnytsia: Vasyl Stus DonNU

13. Matvienko, T., Tsesliv, O., (2009). Short-term forecasting research - Brown's model. Current problems of economics and management: a collection of scientific works of young scientists, 3

14. Most likely lucky, that's just what? Analysis of the freight market in Ukraine [Electronic resource] // Pro Capital Group. - 2019. - Resource access mode: https://proconsulting.ua/ua/services?type 